\title{
Attitude of women in a Nigerian local government to reproductive health following health education intervention
}

\author{
Chinedu Arthur Idoko ${ }^{1}$, Chinelo Ifeoma Idoko², Ikechukwu Christian Chidolue ${ }^{1}$
}

1. Department of Community Medicine, College of Medicine, University of Nigeria.

2. Department of Business Administration Enugu State University of Science \& Technology (ESUT) Business School.

\begin{abstract}
Background: Health Education on reproductive health issues is indispensible in fostering safe sexual and reproductive health more so in rural populations. This study aimed at reflecting the role of health education in improvement of attitude of women to reproductive health in a rural Nigerian Local Government (LG).

Methods: There was a pre-intervention, intervention and post-intervention stages in this cross-sectional study. Baseline data was collected from study and control groups after which health education was only administered to study group. Post-intervention data was collected thereafter. Chi-square Test was used to test for any significant differences while multiple regression analysis was done for factors affecting reproductive health.

Results: We found a statistically significant increase in parameters relating to study respondents' attitude to reproductive health post intervention, $(p=0.000$ for condoms use and concern about risk of STIs). This was not same for the control group.

Conclusion: A significant number of women proved a better and positive attitude to reproductive health after intervention such as improved use of condoms to evade risks associated with unprotected sex, concern about risk of HIV and STIs

Keywords: Health Education, Reproductive Health, Attitude, women, Nigerian LG.

DOI: https://dx.doi.org/10.4314/ahs.v19i4.23

Cite as: Idoko CA, Idoko CI,Chidolue IC. Attitude of women in a Nigerian local government to reproductive health following health education intervention. Afri Health Sci.2019;19(4):3018-3026.https:/ / dx.doi.org/ 10.4314 / abs.v19i4.23
\end{abstract}

\section{Introduction}

\section{Background of study}

Health care needs (information and services) of most Nigerians rural populaces are largely unmet. ${ }^{1}$ Evidence of unmet needs is largely reflected in engagement in risky sexual behaviour as well as harbouring several misconceptions. Such misconceptions include belief that pregnancy cannot occur during first sexual episode as well as that use of contraceptives can cause infertility. ${ }^{2,3}$ Unprotected sex for instance is viewed as not risky especially in unmarried women because the partner is regular as opposed to a casual one. Although these serially monogamous pairings

\section{Corresponding author: \\ Chinedu Arthur Idoko, Department of Community Medicine, College of Medicine, University of Nigeria Phone: 08037219872 \\ Email: chineduarthur@yahoo.com}

may be of short duration, their regular status erroneously confers safety with respect to STD transmission. ${ }^{4} \mathrm{Un}$ protected sex thus occurs with multiple partners, but the cumulative risk is rendered invisible by the apparent monogamy and commitment of each discrete relationship. The society is therefore exposed to sexual risks that at risk group may not have the full import of. This sets the background for this interventional study.

Health Education can be defined as the principle by which individuals and groups of people learn to behave in a manner conducive to the promotion, maintenance, or restoration of health. Benefits include awareness creation to health promotion, preventive, curative methods thereby equipping the populace with the appropriate knowledge and necessary attitude to maintain good health. 4 A number of studies have reflected the importance of health education in the improvement of knowledge and attitude of women in matters of health thereby reinforcing the vital importance of this tool in health promotion. 5,6

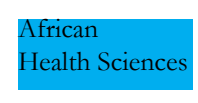

3018
(C) 2019 Idoko et al. Licensee African Health Sciences. This is an Open Access article distributed under the terms of the Creative commons Attribution License (https://creativecommons.org/licenses/BY/4.0), which permits unrestricted use, distribution, and reproduction in any medium, provided the original work is properly cited. 


\section{Health education theoritical model}

Health Education is the transmission of what is known about health into desirable individual and community behaviour patterns by means of an educational process. It is looked at as a process that informs, motivates and helps people to adopt and maintain the positive health behaviours. It combines personal and collective intervention strategies to develop the knowledge and competencies required to take better decisions related to health., There are different health education theoretical models, part of which is the Theory of Reasoned Action, Trans-theoretical Model, the Social Cognitive Theory, Communications Theory and the Coping theory. 9 The theory of reasoned action was founded by Icek Ajzen and Martin Fishben. ${ }^{8}$

The theorists of the theory of reasoned action began with the interesting notion that we should be able to explain or predict human behaviour by positing that the best way to predict someone's action, is to ask them what they intend to do within a reasonably proximal time range.

The theorists determined that one's attitude is best predicted by examining what he/ she expects to be the outcome of a particular action and his/ her evaluation of the likelihood of this action. ${ }^{9}$

This theory of Reasoned Action was utilized in shaping the research questions, intervention, data collection and interpretation of the research findings. This was by the assumption that the respondents' answer to what intend to do within a reasonably proximal time range is a prediction of their future action. There was therefore an attempt to modify their future actions by education and information intervention provided in order to change their perspective; which invariably would translate to a positive action in the future. The questions asked sought their dispositions at the point and subsequently after heath education intervention. This was after all statistically analysed for significance.

There, is now strong evidence from an increasing number of studies that health education applied in an appropriate context, changes behaviour-including behaviour in sensitive and difficult areas where knowledge-based health education has failed. ${ }^{9}$

In a particular study for instance it was found that the attraction to sex in teenagers is associated with more con- versations related to sexual matters. The study therefore evaluated the effect of organizing these interactions using peer education in schools on the knowledge and attitude toward sexual health and found a statistically significant relationship. ${ }^{10}$

Another study also found out that education has an important role in promoting knowledge of people at risk about HIV/ AIDS prevention. ${ }^{11,12}$ Women in rural areas of Nigeria are very impressionable. The fact that information, awareness is not as pronounced in the urban populaces makes it especially more expedient to conduct this kind of intervention in these extractions. The dearth of information on similar studies in this area of the world furthermore necessitates an intervention as this.

Research questions in this study include what the baseline attitude of the women is to reproductive health and issues, what effect health education has in re-shaping the attitude following intervention while the aim is to determine the effect of health education on the attitude of women in Igbo-Eze North Local Government Area.

\section{Methods}

\section{Study area and population}

The study was carried out in Igbo-Eze North Local Government Area (LGA). Igbo-Eze North with a population of 259,431 at the 2006 census is a Local Government Area in the North of Enugu state, Nigeria.5,6 It consisted of women within the child bearing age of 15-49 years in Igbo-Eze North Local Government Area. The Control group was women in the child bearing age of 15-49 years in Igbo-Etiti Local Government Area.

\section{Study design}

A cross-sectional study carried out in Pre-intervention, intervention and post-intervention phases. Baseline data was collected from the study and control groups after which health education was offered the study but not the control group. Health Education sessions consisted of modules covering family planning, Sexually Transmitted Diseases (STDs), abortions and associated risks amongst others.

Data was again collected immediately after for the study group and again 3 months after for the study and control groups. 


\section{Inclusion criteria}

Females within the age group of 15-49 years in Igbo-Eze North and Igbo-Etiti L.G.As and are available and willing to participate in the study.

\section{Exclusion criteria}

Females who were younger than 15 years or older than 49 years in the target area as at the time of the study were excluded from the pre and post intervention assessment but were allowed to benefit from the intervention.

\section{Sample size determination}

Using the formula7,9, $11 \quad \mathrm{~N}=2$. [Zcrit $[2 \mathrm{Pk}(1-\mathrm{Pk})]^{1 / 2}$

+ Zpwr $\left.[\mathrm{P} 1(1-\mathrm{P} 1)+\mathrm{P} 2(1-\mathrm{P} 2)]^{1 / 2}\right] 2 / \mathrm{D} 2$

Where $\mathrm{N}=$ Total Sample Size (the sum of the sizes of both comparison groups)

$\mathrm{P}=$ The arithmetic average of the proportion of the target population estimated to be exhibiting expected reproductive health attitude taken at 10\% from a study done in 2008.10

P1 and P2 are partial estimates of the two proportions to be compared

P1-P2 = Margin of error tolerated $=$ (i.e. the minimum expected difference)

$\mathrm{Pk}=(\mathrm{P} 1+\mathrm{P} 2) / 2$

Zcrit $=1.960$ (i.e. the standard normal deviate corresponding with 1.96 at $95 \%$ confidence limit

Zpwr $=0.842$ (i.e. the power).

364 was derived as the sample size. Considering 10\% for non-response, 400 was the sample size to be studied for both study and control group respectively but for this study, 524/ 514 and 518/ 510 women were studied for study and control groups respectively for pre and post intervention on the understanding that increase in sample size makes for more accuracy of the study results.

\section{Sampling method}

Purposive sampling was applied in choosing the study and control areas while the cluster sampling and systematic sampling techniques was respectively employed to pick houses and decide on ones within the cluster for the study. Map of Local Government was called up and divided into zones ensuring no overlap; 3 zones were selected to give a wider spread. Furthermore, systematic sampling technique was then applied to pick houses within the cluster for the study by creating a sampling frame after which sampling interval was derived. Subsequently, a random start was selected and researchers moved from house to house (applying the sampling interval) in the cluster collecting data until sample size was achieved.

\section{Data collection methods}

Research assistants were trained on reproductive health topics for 2 days; two hours a day. Advocacy was also done prior to data collection. There were three phases of data collection.

\section{Statistical analysis}

Questionnaires were checked for completeness and variables analyzed using the EPI-INFO software version 6.0 (developed by the Centres for Disease Control) which generated frequency tables and percentages.

Chi-square analysis was done and statistical significance tested for any significant differences between the pre and post intervention and between the results at the 2 points of post intervention. Results are displayed on tables. The before-and-after of the control study designs was furthermore subjected to a difference-in-differences analysis.

\section{Ethical considerations}

Ethical clearance was obtained from the ethics review committee of the University of Nigeria Teaching Hospital. Permission for the study sought from the two LGAs secretariat.

Informed verbal consent was obtained from the respondents with confidentiality maintained. Health Education on Reproductive Health was offered to the control group at the end of the study (but not within the study period) as a follow up for ethical reasons.

\section{Results}

Table 1 reveals no statistically significant difference (P $>0.05)$ between the study and control groups by all socio-demographic characteristics assessed. 
Table 1: Baseline socio-demographic data

\begin{tabular}{|c|c|c|c|}
\hline Variable & $\begin{array}{l}\text { Study group } \\
\text { n=524 } \\
\text { Freq. }(\%)\end{array}$ & $\begin{array}{l}\text { Control group } \\
\text { n=518 } \\
\text { Freq. }(\%)\end{array}$ & $\begin{array}{l}\text { Baseline } \\
\text { Chi-square (p- } \\
\text { value) }\end{array}$ \\
\hline $\begin{array}{l}\text { Age group: } \\
15-24 \\
25-34 \\
35-49\end{array}$ & $\begin{array}{l}131(25.0) \\
200(38.2) \\
193(36.8)\end{array}$ & $\begin{array}{l}168(32.1) \\
184(35.2) \\
166(31.7)\end{array}$ & $7.242(0.027)$ \\
\hline $\begin{array}{l}\text { Occupation: } \\
\text { Housewife } \\
\text { Farmer } \\
\text { Trader } \\
\text { Others }\end{array}$ & $\begin{array}{c}128(24.4) \\
205(39.1) \\
148(28.3) \\
43(8.2)\end{array}$ & $\begin{array}{l}136(26.3) \\
147(28.4) \\
176(33.9) \\
59(11.4)\end{array}$ & $14.695(0.002)$ \\
\hline $\begin{array}{l}\text { Marital status: } \\
\text { Single } \\
\text { Married } \\
\text { Divorced } \\
\text { Separated } \\
\text { Widowed }\end{array}$ & $\begin{array}{l}96(18.3) \\
374(71.4) \\
17(3.2) \\
25(4.8) \\
12(2.3)\end{array}$ & $\begin{array}{l}84(16.2) \\
384(74.1) \\
17(3.3) \\
25(4.8) \\
8(1.6)\end{array}$ & $1.697(0.791)$ \\
\hline $\begin{array}{l}\text { Type of Marriage: } \\
\text { Monogamous } \\
\text { Polygamous }\end{array}$ & $\begin{array}{l}409(78.0) \\
115(22.0)\end{array}$ & $\begin{array}{r}421(81.3) \\
97(18.7)\end{array}$ & $1.667(0.197)$ \\
\hline $\begin{array}{l}\text { No of Children: } \\
0-4 \\
5-9 \\
10-15\end{array}$ & $\begin{array}{r}199(38.0) \\
262(50.0) \\
63(12.0)\end{array}$ & $\begin{array}{c}218(42.1) \\
271(52.3) \\
29(5.6)\end{array}$ & $13.549(0.001)$ \\
\hline $\begin{array}{l}\text { Tribe: } \\
\text { Ibo } \\
\text { Others }\end{array}$ & $\begin{array}{l}488(93.1) \\
36(6.9)\end{array}$ & $\begin{array}{l}501(96.7) \\
17(3.3)\end{array}$ & $6.946(0.008)$ \\
\hline $\begin{array}{l}\text { Religion: } \\
\text { Christianity } \\
\text { Others }\end{array}$ & $\begin{array}{l}492(93.9) \\
32(6.1)\end{array}$ & $\begin{array}{l}479(92.5) \\
39(7.5)\end{array}$ & $0.830(0.362)$ \\
\hline $\begin{array}{l}\text { Education: } \\
\text { No Education } \\
\text { Completed Prim } \\
\text { Educ. } \\
\text { Uncompleted Pri. } \\
\text { Edu. } \\
\text { Completed Sec. Edu. } \\
\text { Uncompleted Sec. } \\
\text { Edu. } \\
\text { Tertiary Education }\end{array}$ & $\begin{array}{l}34(6.5) \\
210(40.1) \\
45(8.6) \\
131(25.0) \\
54(10.3) \\
50(9.5)\end{array}$ & $\begin{array}{l}26(5.0) \\
217(41.9) \\
34(6.6) \\
148(28.6) \\
69(13.3) \\
24(4.6)\end{array}$ & $14.679 .012)$ \\
\hline
\end{tabular}

Table 2 shows that the study respondents' attitude to reproductive health such as use of condoms and concern about risk of STIs improved appreciably post-interven- tion. The same could not be said of the control group that received no intervention. Post-intervention, there was a statistically significant difference in respondents' attitude to reproductive health $(\mathrm{p}=0.000)$ 
Table 2: Respondents' attitude to reproductive health issues

\begin{tabular}{|c|c|c|c|c|c|c|c|}
\hline \multirow[t]{2}{*}{ Variable } & \multicolumn{2}{|c|}{ Study group } & & \multicolumn{2}{|c|}{ Control group } & \multirow[b]{2}{*}{ Difference } & \multirow{2}{*}{$\begin{array}{l}\text { Difference- } \\
\text { in- } \\
\text { differences }\end{array}$} \\
\hline & $\begin{array}{l}\text { Before } \\
n=524 \\
\text { Freq. } \\
(\%)\end{array}$ & $\begin{array}{l}\text { After } \\
n=514 \\
\text { Freq. }(\%)\end{array}$ & Difference & $\begin{array}{l}\text { Before } \\
\mathrm{n}=518 \\
\text { Freq. }(\%)\end{array}$ & $\begin{array}{l}\text { After } \\
\mathrm{n}=510 \\
\text { Freq. }(\%)\end{array}$ & & \\
\hline \multirow[t]{2}{*}{$\begin{array}{l}\text { Women } \\
\text { education on } \\
\text { Reproductive } \\
\text { Health is } \\
\text { important } \\
\text { Agree } \\
\text { Strongly agree } \\
\text { Disagree } \\
\text { Strongly } \\
\text { disagree }\end{array}$} & $\begin{array}{l}64 \\
(12.5) \\
50(9.7) \\
171 \\
(32.6) \\
64 \\
(12.2)\end{array}$ & $\begin{array}{l}113(21.6) \\
176(33.6) \\
207(40.3) \\
193(37.5)\end{array}$ & $\begin{array}{l}49 \\
126 \\
36 \\
129\end{array}$ & $\begin{array}{l}130(25.1) \\
180(37.8) \\
168(32.4) \\
40(7.7)\end{array}$ & $\begin{array}{l}144(28.2) \\
151(29.6) \\
164(32.2) \\
51(10.0)\end{array}$ & $\begin{array}{l}14 \\
-29 \\
-4 \\
11\end{array}$ & $\begin{array}{l}35 \\
155 \\
40 \\
118\end{array}$ \\
\hline & \multicolumn{2}{|c|}{$\begin{array}{l}\text { Chi-square }=45.507 \\
\text { p }=0.000\end{array}$} & & \multicolumn{2}{|c|}{$\begin{array}{l}\text { Chi-square }=4.572 ; \\
\mathbf{p}=0.206\end{array}$} & & \\
\hline \multirow[t]{2}{*}{$\begin{array}{l}\text { Condoms } \\
\text { should be used } \\
\text { first time one } \\
\text { has sex outside } \\
\text { marriage } \\
\text { Agree } \\
\text { Strongly agree } \\
\text { Disagree } \\
\text { Strongly } \\
\text { disagree }\end{array}$} & $\begin{array}{l}196 \\
(37.4) \\
108 \\
(20.6) \\
104 \\
(19.9) \\
116 \\
(22.1) \\
\end{array}$ & $\begin{array}{l}265(51.5) \\
168(32.7) \\
45(8.8) \\
36(7.0)\end{array}$ & $\begin{array}{l}69 \\
60 \\
-59 \\
-80\end{array}$ & $\begin{array}{l}184(35.5) \\
144(27.8) \\
113(21.8) \\
77(14.9)\end{array}$ & $\begin{array}{l}176(34.5) \\
133(26.0) \\
127(25.0) \\
74(14.5)\end{array}$ & $\begin{array}{l}-8 \\
-11 \\
14 \\
-3\end{array}$ & $\begin{array}{l}61 \\
71 \\
-73 \\
-77\end{array}$ \\
\hline & \multicolumn{2}{|c|}{$\begin{array}{l}\text { Chi-square }=88.751 \\
\text { p }=0.000\end{array}$} & & \multicolumn{2}{|c|}{$\begin{array}{l}\text { Chi-square }=1.429 \\
\text { p }=0.699\end{array}$} & & \\
\hline \multirow[t]{2}{*}{$\begin{array}{l}\text { One should be } \\
\text { concerned } \\
\text { about risk of } \\
\text { HIV \& STIs } \\
\text { Agree } \\
\text { Strongly agree } \\
\text { Disagree } \\
\text { Strongly } \\
\text { disagree }\end{array}$} & $\begin{array}{l}261 \\
(49.8) \\
167 \\
(31.9) \\
60 \\
(11.5) \\
36(6.8) \\
\end{array}$ & $\begin{array}{l}287(55.8) \\
184(35.8) \\
29(5.7) \\
14(2.7)\end{array}$ & $\begin{array}{l}26 \\
17 \\
-31 \\
-22\end{array}$ & $\begin{array}{l}259(50.0) \\
161(31.1) \\
58(11.2) \\
40(7.7)\end{array}$ & $\begin{array}{l}256(50.2) \\
144(28.2) \\
61(12.0) \\
49(9.6)\end{array}$ & $\begin{array}{l}-3 \\
-17 \\
3 \\
9\end{array}$ & $\begin{array}{l}29 \\
34 \\
-28 \\
-31\end{array}$ \\
\hline & \multicolumn{2}{|c|}{$\begin{array}{l}\text { Chi-square }=22.440 \\
\text { p }=0.000\end{array}$} & & \multicolumn{2}{|c|}{$\begin{array}{l}\text { Chi-square }=1.889 \\
\mathbf{p}=0.596\end{array}$} & & \\
\hline
\end{tabular}

Table 3 revealed no commensurate improvement in attitude to risk of STIs in the control group that received health education sessions only after the study as against the study group. It can be inferred from the analysis that there exists a statistically significant difference post-intervention in parameters, indicating a positive attitude to
STIs risk $(\mathrm{p}<0.05)$.

In Table 4, we found no statistically significant difference post intervention of respondents' attitude to abortion ( $p$ $=0.126)$

Table 5 shows a multiple regression analysis of factors affecting attitude to reproductive health issues. 
Table 3: Respondents' attitude to risk of STIs

\begin{tabular}{|c|c|c|c|c|c|c|c|}
\hline & \multicolumn{2}{|c|}{ Study group } & \multirow[b]{2}{*}{ Difference } & \multicolumn{2}{|c|}{ Control group } & \multirow[b]{2}{*}{ Difference } & \multirow{2}{*}{$\begin{array}{l}\text { Difference- } \\
\text { in- } \\
\text { differences }\end{array}$} \\
\hline & $\begin{array}{l}\text { Before } \\
n=524 \\
\text { Freq. (\%) }\end{array}$ & $\begin{array}{l}\text { After } \\
\mathrm{n}=514 \\
\text { Freq. (\%) }\end{array}$ & & $\begin{array}{l}\text { Before } \\
\mathrm{n}=518 \\
\text { Freq. (\%) }\end{array}$ & $\begin{array}{l}\text { After } \\
\mathrm{n}=510 \\
\text { Freq. } \\
(\% 0\end{array}$ & & \\
\hline $\begin{array}{l}\text { Following will } \\
\text { limit risk of } \\
\text { STIs: } \\
\text { Faithfulness to } \\
\text { partner } \\
\text { Agree } \\
\text { Strongly agree } \\
\text { Disagree } \\
\text { Strongly disagree }\end{array}$ & $\begin{array}{l}96(18.3) \\
72(13.7) \\
197 \\
(37.6) \\
159 \\
(30.4) \\
\text { Chi- } \\
\text { square = } \\
110.030 \\
\mathbf{p}= \\
0.000\end{array}$ & $\begin{array}{l}188(36.6) \\
144(28.0) \\
99(19.3) \\
83(16.1)\end{array}$ & $\begin{array}{l}92 \\
72 \\
-98 \\
-76\end{array}$ & $\begin{array}{l}84(16.2) \\
61(11.8) \\
207 \\
(40.0) \\
166 \\
(32.0) \\
\text { Chi- } \\
\text { square }= \\
6.569 \\
\mathbf{p}= \\
0.087 \\
\end{array}$ & $\begin{array}{l}73(14.3) \\
88(17.3) \\
199 \\
(39.0) \\
150 \\
(29.4)\end{array}$ & $\begin{array}{l}-11 \\
27 \\
-8 \\
-16\end{array}$ & $\begin{array}{l}103 \\
99 \\
-90 \\
-60\end{array}$ \\
\hline $\begin{array}{l}\text { Abstinence } \\
\text { Agree } \\
\text { Strongly agree } \\
\text { Disagree } \\
\text { Strongly disagree }\end{array}$ & $\begin{array}{l}108 \\
(20.6) \\
93(17.7) \\
131 \\
(25.0) \\
192 \\
(36.7)\end{array}$ & $\begin{array}{l}130(23.3) \\
151(27.5) \\
98(21.0) \\
135(28.2)\end{array}$ & $\begin{array}{l}22 \\
58 \\
-33 \\
-57\end{array}$ & $\begin{array}{l}101 \\
(19.5) \\
115 \\
(22.2) \\
126 \\
(24.3) \\
176 \\
(34.0)\end{array}$ & $\begin{array}{l}95(18.6) \\
124 \\
(24.3) \\
96(18.8) \\
195 \\
(38.2)\end{array}$ & $\begin{array}{l}-6 \\
9 \\
-30 \\
19\end{array}$ & $\begin{array}{l}28 \\
49 \\
-3 \\
-76\end{array}$ \\
\hline & \multicolumn{2}{|c|}{$\begin{array}{l}\text { Chi-square }=30.418 \\
\mathbf{p}=0.000\end{array}$} & & \multicolumn{2}{|c|}{$\begin{array}{l}\text { Chi-square }=15.488 \\
\text { p }=0.139\end{array}$} & & \\
\hline
\end{tabular}

Table 4: Respondents' attitude to abortion

\begin{tabular}{|c|c|c|c|c|c|c|c|}
\hline \multirow[t]{2}{*}{ Variable } & \multicolumn{2}{|c|}{ Study group } & & \multicolumn{2}{|c|}{ Control group } & \multirow[b]{2}{*}{ Difference } & \multirow{2}{*}{$\begin{array}{l}\text { Difference- } \\
\text { in- } \\
\text { differences }\end{array}$} \\
\hline & $\begin{array}{l}\text { Before } \\
\mathrm{n}=524 \\
\text { Freq. (\%) }\end{array}$ & $\begin{array}{l}\text { After } \\
\mathrm{n}=514 \\
\text { Freq. (\%) }\end{array}$ & Difference & $\begin{array}{l}\text { Before } \\
\mathrm{n}=518 \\
\text { Freq. } \\
(\%)\end{array}$ & $\begin{array}{l}\text { After } \\
\mathrm{n}=510 \\
\text { Freq. (\%) }\end{array}$ & & \\
\hline $\begin{array}{l}\text { Abortion is } \\
\text { necessary } \\
\text { Agree } \\
\text { Strongly } \\
\text { agree } \\
\text { Disagree } \\
\text { Strongly } \\
\text { disagree }\end{array}$ & $\begin{array}{l}104 \\
(19.8) \\
99(18.9) \\
144 \\
(27.5) \\
177 \\
(33.8)\end{array}$ & $\begin{array}{l}84(16.3) \\
81(15.8) \\
168(32.7) \\
181(35.2)\end{array}$ & $\begin{array}{l}-20 \\
-18 \\
24 \\
4\end{array}$ & $\begin{array}{l}113 \\
(21.8) \\
103 \\
(19.9) \\
136 \\
(26.3) \\
166 \\
(32.0)\end{array}$ & $\begin{array}{l}97(19.0) \\
107(21.0) \\
141(27.6) \\
165(32.4)\end{array}$ & $\begin{array}{l}-16 \\
4 \\
5 \\
-1\end{array}$ & $\begin{array}{l}-4 \\
-22 \\
19 \\
5\end{array}$ \\
\hline & \multicolumn{2}{|c|}{$\begin{array}{l}\text { Chi-square }=5.723 \\
\mathbf{p}=0.126\end{array}$} & & \multicolumn{2}{|c|}{$\begin{array}{l}\text { Chi-square }=1.326 \\
\mathrm{P}=0.723\end{array}$} & & \\
\hline
\end{tabular}


Table 5: Analysis of factors affecting attitude to reproductive health issues using multiple regression analysis

\begin{tabular}{|c|c|c|c|c|}
\hline Predictor & B & $\begin{array}{l}\text { Standard } \\
\text { Error } \\
\text { (SE) }\end{array}$ & $\begin{array}{l}\text { Odds Ratio } \\
(\operatorname{Exp} \beta)\end{array}$ & Sign \\
\hline $\begin{array}{l}\text { Age (years) } \\
\text { Less than } 25 \text { (Ref.) } \\
\text { More than or equal to } 25\end{array}$ & -0.62 & 6.01 & 2.73 & NS \\
\hline $\begin{array}{l}\text { Education level } \\
\text { None or Primary (Ref.) } \\
\text { Secondary and above }\end{array}$ & 8.84 & 3.64 & 49.34 & $X$ \\
\hline $\begin{array}{l}\text { Current number of living } \\
\text { children } 3 \text { and below } \\
\text { (Ref.) } 4 \text { and above }\end{array}$ & 9.69 & 3.02 & 64.0 & $\mathrm{XX}$ \\
\hline $\begin{array}{l}\text { Concern about risk of } \\
\text { contracting HIV/AIDS } \\
\text { and other STIs } \\
\text { No (Ref.) } \\
\text { Yes }\end{array}$ & 9.50 & 2.90 & 60.0 & XX \\
\hline $\begin{array}{l}\text { Thinking that it is } \\
\text { important for women to } \\
\text { be educated on issues } \\
\text { concerning their } \\
\text { reproductive life } \\
\text { No (Ref.) } \\
\text { Yes }\end{array}$ & 6.96 & 2.21 & 27.63 & $X$ \\
\hline
\end{tabular}

Ref. $=$ Reference Category; NS: Non Significant $(\mathrm{P}>0.05) ; \mathrm{X}=$ Significant $(\mathrm{P}<0.05) ; \mathrm{X}=$ Significant at $\mathrm{P}<0.01$.

\section{Discussion}

Women have differing attitudes to sexual issues that is influenced by different factors. The sexual attitudes of females have been found to be more influenced by family factors and the males by more individual factors. ${ }^{13,14}$

In this study, the attitude to reproductive health issues of the study and control respondents was generally found to be positive as a greater percentage agreed and strongly agreed to assertions on positive reproductive health living. That disposition positive attitude however improved post-intervention.

On utilization of condom at first sexual intercourse, $19.9 \%$ and $21.8 \%$ of study and control respondents respectively believed that condom should not be used the first time one has sex. Previous studies however reported a higher prevalence of non-use of condom at first sexual initiation. Izugbara 2 in the Southern part of Nigeria reported that $92 \%$ of females' adolescents did not use any form of protection at first sexual encounter. Also, another study 4 found that majority of their respondents did not use any family planning device at sexual initiation. These statistics give an indication of the risks of sexually transmitted infection including HIV/AIDS that women are exposed to at first sexual intercourse. Coupled with this is the risk of unwanted pregnancies with its attendant problem of unsafe abortion and possible complications. Although attitudinal change is a long-term process which is gradual, the respondent's attitude to sex, condom use, and sexuality education increased significantly $(\mathrm{p}<0.05)$ within the 3 months interval. The result is in concordance with that of findings in similar studies. ${ }^{2,4}$ The increase in contraceptive use was not entirely unexpected as a good reproductive health education should usually generate a demand for other services and referrals, especially personal counselling and health services. 
On the issue of concern to HIV/ AIDS, and STIs risks, there was a statistically significant increase for the study group post intervention. These results was concurrent with findings in similar studies. ${ }^{2,4}$

Respondents that agreed to abstinence as a means of limiting the risk of HIV/AIDS especially in unmarried single increased significantly in the study group $(p<0.05)$. This finding highlights the importance of Family Life Education as put forward by many authors ${ }^{15,16,17,18,19,20,21}$ who have found out that it is an important tool in reducing risky sexual behaviours.

A greater percentage of study respondents furthermore agreed to faithfulness to partner as a means of reducing risk to HIV/ AIDS post intervention compared to response prior study. This was also statistically proven. This finding is in agreement with previous studies ${ }^{22,23}$, $24,25-28$ where it was shown that family life education programmes can increase knowledge about reproductive health and foster positive attitudes towards health and moral behaviour. This improvement in knowledge following health education will result in better perception of reproductive health issues and eventually lead to better attitude over the long term. It will furthermore reduce marital as well as societal frictions like sexual violence as awareness creates attitudinal change. ${ }^{20,21}$

\section{Study limitations}

1. Concurrent health education of the respondents in both study and control groups on issues relating to reproductive health during the time of the study from other sources (e.g. mass media) could not be prevented. This was accounted for in the margin of error.

2. There may have been some degree of flow/ sharing of information between the study and control group in the community, market place or places of religious worship. This was controlled by taking cognizance of at least a $10 \mathrm{~km}$ distance between the study and control group populations.

3. Discussions on reproductive health issues in this environment are seen as sensitive issues and hence the responses may have been somewhat inhibited. In controlling this, the respondents were reassured of confidentiality of information, intended specific use of the information provided; and hence need for sincerity and factual response.

\section{Conclusion}

Attitudes to reproductive health issues such as use of condoms in premarital and sex outside marriage as well as concern on risk of HIV and STIs improved considerably post intervention. The intervention can therefore be said to have had a significant impact on attitude.

\section{Recommendations}

Replication of such health education interventions will go a long way in fostering safe sexual and reproductive health amongst rural women.

Institutionalization of health education in health facilities ante-natal services were not yet practiced.

\section{Acknowledgments}

We would like to appreciate all the authors for their commitment and drive to every processes of getting this paper to a publishable phase.

\section{Conflict of interest}

None declared.

\section{References}

1. Amazigo U, Silva N, Kaufman J, Obikeze DS: Sexual activity and contraceptive knowledge and use among inschool adolescents in Nigeria. International Family Planning Perspective. 1998, 23 (1): 28-33.

2. Izugbara CO. Tasting the forbidden fruit: The Social Context of First Sexual Intercourse among Young Persons in a rural Nigerian community. Afri J. Reprod Health 2001; 5 (2): 22-29.

3. Slap GB, Lot L, Huang B, Daniyan CA, Zink TM, Succop PA: Sexual behaviour among adolescents in Nigeria: cross sectional survey of secondary school students. Brit Med J 2003: 1-6.

4. Grinley D, Riley G, Bellis J, et al. Assessing the stages of change and decision making for contraceptive use for the prevention of pregnancy, STDs and AIDS. Health Educ Q. 1993; 20: 455-470 PubMed .

5. Igbo Eze North- expand Your Mind-Revolvy. Available from www.revolvy.com/main/index.plp. Accessed 01/12/2016.

6. Programmes: Igbo-Eze North. Available from www. repository.unn.edu.ng:8080/ Accessed 01/12/2016.

7. Babbie E. The practice of Social Research. Behmont, CA. $10^{\text {th }} \mathrm{Ed},(2003) ; 4-15$. 
8. Feishbein M, Arjzen I. The theory of Reasoned Action (TRA).Addison-Wesley. 1980; pp. 11-19.

9. Idoko CA, Omotowo B, Agunwa C, Okeke C, Obi I, $\mathrm{Ndu} A$, et al. Effect of Health Education on Reproductive health Knowledge of Women in Two Local Government Areas (LGAs) of Enugu State, South Eastern Nigeria; a Cross Sectional Study. International Journal of Medicine and health Development. 2017, Vol. 22 (2). Xxxxx

10. Jodati AR, Nourabadi GR, Hassanzadeh S, Dastgiri $\mathrm{S}$, Sedaghat K. Impact of education in promoting the knowledge of and attitude to HIV/AIDS prevention: a trialon 17,000 Iranian students. Int J STD. 2007 Jun; 18 (6): 407-9.).

11. Taylor DW. The calculation of sample size and power in planning of experiments. Department of Clinical Epidemiology and Biostatistics. McMaster University, Hamilton, Ontario; 1994.

12. Adebamowo CA. Ezeome RE. Ajuwon JA. Ogundiran TO. Survey of knowledge, attitude and practice of Nigerian surgery trainees to $\mathrm{HIV}$-infected persons and AIDS patients. BMC Surgery. 2002; 1:7.

13. Moreau-Gruet F, Ferron C, Jeanin A, Dubois-Arber F. Adolescent Sexuality. The gender gap. AIDS Care. 1996; 8 (6): 64-653.

14. Werner-Wikson RI. Gender differences in adolescent sexual attitudes. The influence of individual and family factors. Adolescence. 1998; 33 (131): 519-531.

15. Adegbenga MS, Dipelo M, Babalola S, Otu DA. Repropductive knowledge, sexual behaviour and Contraceptive Use among Adolescents in Niger State of Nigeria. Afri J. Reprod Health 2003; 7: 36-48 PubMed .

16. Bleek W. Induced abortion in a Ghanaian family. African Studies Review 1978: 21: 103-20.

17. Castle S. Factors influencing Young Malians' Reluc- tance to Using Hormonal Contraceptives. Studies in Family Planning. 2003; 34 (3): 186-199.

18. Hochbaum G. Health Behaviour; basic concepts in Health Series. National Centre for Health Services Research \& Development. 1983.

19. Hoffmann AD. Contraception in Adolescence-a Review. Bulletin of the World Health Organization. 1984; 62 (1): 151-162.

20. Asindi AA, Ibia EO, Young MU. Acquired Immunodeficiency Syndrome: education, exposure, knowledge and attitude of Nigerian adolescents in Calabar. Afr Trop Paed. 1992; (12) 40: 397-402.

21. Olayinka BA, Osho AA. Changes in attitude, sexual behaviour and the risk of HIV/AIDS transmission in south-west Nigeria. E/Afr Med J. 1997; 74, (9):554-560.

22. Omorodion FI, Olusanya O. The Social Context of Reported Rape in Benin City. African J. Reprod Health. 1998; 2 (2): 37-43.

23. Amir M. Patterns of Forcible Rape. Chicago, University Press. 1971.

24. Ogbuji CQ. Violence against Women: Impact on their Reproductive Health. Trop J. Obstet Gynaecol. 2004; 21: 6164 PubMed.

25. Joseph P. "Children who are Victims of Sexual assault and the Psychology of Offenders." American Journal of Psychotherapy. 1976; 30: 401.

26. Becker JV, Skinner LJ, Abel GG, Treacy EC. "Incidence and types of sexual dysfunctions in rape and incest victims." Journal of Sex and Marital Therapy. 1982; 8: 65- 74. 27. Heise L, Ellsberg M, Gottenmoeller M. Finding violence against women. Population Report Series L. No 11, 1999.

28. Ajuwon AJ, Olley BO, Akin-Jimoh I, Akintola O. Experience of Sexual Coercion among Adolescents in Ibadan, Nigeria. Afr J of Reprod Health. 2001; 5 (3): 120131. 